\title{
EFFECTS OF ENTREPRENEURSHIP EDUCATION AS AN ENTREPRENEURIAL PERSONALITY TRAIT MODEL UNDER ENTREPRENEURIAL INTENTION FOR THE FUTURE IN SURABAYA
}

\author{
Vanessa \& Krismi Budi Sienatra \\ Fakultas Manajemen dan Bisnis, Universitas Ciputra
}

\begin{abstract}
Entrepreneurship is an important sector that sustains a country's economic growth. Entrepreneurs must have entrepreneurial personality traits which are obtained from formal education. The purpose of this research is to analyze the effects of entrepreneurial personality traits that consist of self-efficacy, proactive personality, and locus of control and entrepreneurship education as a moderating variable on entrepreneurial intention. The population in this research include active business management students in Surabaya. Accidental sampling technique enables the researchers to get the total samples of 152 people by distributing questionnaires. The research method is multiple linear regression whose goal is to find out the effects of the independent variables on the dependent variable. Meanwhile, determination coefficient analysis is employed to find out the effect of the moderating variable. The results of the multiple linear regression analysis show that self-efficacy, proactive personality, and locus of control significantly effect on entrepreneurial intention. The results of this research also show that entrepreneurship education is able to moderate selfefficacy on entrepreneurial intention.
\end{abstract}

Keywords: entrepreneurial intention, self-efficacy, proactive personality, locus of control, entrepreneurship education

\section{INTRODUCTION}

All countries in the world have realized that entrepreneurship is an important sector that supports a country's economic growth (Hermanto \& Suryanto, 2017: 110). The Central Statistics Agency (BPS) noted that the number of Indonesian entrepreneurs increased from 1.67\% at the end of 2014 to $3.1 \%$ at the end of 2018 (jawapos. com, 2019). The increase must be maintained. It is estimated that from 2020 to 2045 , Indonesia will experience a peak era of demographic bonuses (cnnindonesia.com, 2019). Indonesia must take advantage of the imbalance in the number of jobs available compared to the population

*Corresponding Author.

e-mail: vanessaval897@gmail.com caused by demographic bonuses: a reminder of the number of people who are entrepreneurs (Dewi et al., 2018: 17). Therefore, the Indonesian population must be further encouraged to achieve progress in entrepreneurship, where one way is to carry out formal education that emphasizes entrepreneurship (Antonio, 2012: 21; Khalifa \& Dhiaf, 2016: 119).

Entrepreneurs can be formed from entrepreneurial personality traits through formal education that emphasizes entrepreneurship. Some elements of entrepreneurial personality traits are self-efficacy, proactive personality, and locus of control. According to Fuller et al. (2018: 121), self-efficacy is an attitude in which 
Vanessa \& Krismi Budi Sienatra / Effects of Entrepreneurship Education as an Entrepreneurial Personality Trait Model under Entrepreneurial Intention for the Future in Surabaya / JEE, Vol. 9, No. 1, March 2020, pp 29-42

people have confidence in what they can do by maximizing the resources they have. Proactive personality according to Li et al. (2018: 121) is a personality or trait in which people are able to carry out actions regardless of external conditions and this trait enables them to influence their environment and produce change. Locus of Control according to Adnyana and Purnami (2016: 1165) is a condition where individuals are able to control the situation and they will have the influence to make decisions in it. Entrepreneurship education according to Antonio, (2012: 23) is an education that aims to educate students to have the experience to become educated entrepreneurs starting from ideas to the emergence of new ventures. Entrepreneurial intention, according to Karabulut (2016: 16), is the intention or desire of individuals to become entrepreneurs as their career choices and this is an aspect that encourages people to start entrepreneurial actions.

This study aims to examine the effect of entrepreneurial personality traits consisting of selfefficacy, proactive personality, and locus of control on entrepreneurial intention and examine the effect of entrepreneurship education in moderating self-efficacy and entrepreneurial intention.

Zimmerer (1996: 52; in Ranto, 2016: 79) explained that one of the factors driving the growth of the number of entrepreneurs in a country is related to the role of universities in growing one's soul and intention to become entrepreneurs. Previous research by Setiawan (2014) explains that student entrepreneurial intention will not become a reality if students do not have confidence in their ability to become an entrepreneur. Entrepreneurship education has the possibility to become entrepreneurial intention in students. Adnyana \& Purnami (2016: 1164) said that entrepreneurship education will affect self-efficacy towards entrepre- neurial intention. Students gain theoretical and practical knowledge about entrepreneurship in the field and these things make them more confident with their abilities.

Shahab et al. (2019) examined the role of entrepreneurial education in strengthening the relationship of self-efficacy to entrepreneurial intention. He concluded that entrepreneurial education strengthens the relationship of selfefficacy to entrepreneurial intention. Previous research has not comprehensively examined the role of entrepreneurship education in strengthening entrepreneurial intention, and this background is the gap research in this study. Previous studies that have been carried out for example Adnyana and Purnami (2016) and Ghozali and Sahrah (2017) who examined the effect of self-efficacy on entrepreneurial intention of undergraduate students and together produce conclusions that entrepreneurial intention is significantly influenced by self-efficacy. Delle and Amadu (2016) and Mustafa et al. (2016) analyzed the effect of proactive personality on student entrepreneurial intention in Malaysia, and they found that proactive personality had a positive and significant effect on entrepreneurial intention. Karabulut (2016) and Yasir et al. (2017) examined the effect of locus of control on student entrepreneurial intention and both concluded that entrepreneurial intention was positively and significantly influenced by locus of control. From the explanation above and previous research, researchers need to further research on entrepreneurial personality traits and entrepreneurship education in their ability to moderate entrepreneurial intention.

\section{HYPOTHESIS}

This study aims to examine the effect of entrepreneurial personality traits consisting of 
self-efficacy, proactive personality, and locus of control on entrepreneurial intention. In addition, this study aims to examine the extent of the influence of entrepreneurship education moderating self-efficacy and entrepreneurial intention. The hypothesis of this study refers to previous research by Adnyana and Purnami (2016) that examined the effect of self-efficacy on entrepreneurial intention of undergraduate students and resulted in the conclusion that entrepreneurial intention was positively and significantly influenced by self-efficacy. Ghozali and Sahrah (2017) conducted a study that predicted the effect of self-efficacy on entrepreneurial intention and concluded that self-efficacy had a positive and significant effect on entrepreneurial intention. Previous research by Setiawan (2014) explained that entrepreneurial intention from university graduates who teach entrepreneurship education will not become a reality if there is no entrepreneurial personality traits of self-efficacy in themselves. Therefore, hypotheses can be arranged:

H1: Self-efficacy influences students' entrepreneurial intention

Mustafa et al. (2016) analyzed whether proactive personality as one of personality traits affects student entrepreneurial intention in Malaysia. This study found that proactive personality had a significant effect on entrepreneurial intention. Therefore, a hypothesis can be built:

H2: Proactive personality influences students' entrepreneurial intention.

Karabulut (2016) examined the effect of one of the personality traits, locus of control, on entrepreneurial intention. He concluded that entrepreneurial intention was positively and significantly affected by locus of control. Yasir et al. (2017) examined the effect of locus of control on student entrepreneurial intention and he concluded that locus of control and entrepreneurial intention had a positive effect. Therefore, the hypotheses that can be formed are:

H3: Locus of control influences students' entrepreneurial intention.

Shahab et al. (2019) examined the role of entrepreneurial education in strengthening the relationship of self-efficacy to entrepreneurial intention. The study concluded that entrepreneurial education strengthens the relationship of self-efficacy to entrepreneurial intention. Antonio's research (2012) explained that entrepreneurial education is taught in the form of entrepreneurship education under the name "Inspiring Wednesday". Therefore, the hypotheses that can be formed are:

H4: Entrepreneurship education strengthens students' self-efficacy and entrepreneurial intention relationships.

\section{RESEARCH METHODS}

This research uses accidental sampling method and produces a sample of 152 people. They are students in Surabaya who are studying entrepreneurship education at their university. Data obtained by distributing questionnaires.

This study uses 3 types of variables, namely, the independent variable, moderating variable, and the dependent variable used in this study. The dependent variable of this study is entrepreneurial intention $(\mathrm{Y})$. The independent variable or independent variable (X) of this study consisted of self-efficacy (X1), proactive personality (X2), and locus of control (X3). The moderating variable $(\mathrm{Z})$ used in this study is entrepreneurship education. 
Vanessa \& Krismi Budi Sienatra / Effects of Entrepreneurship Education as an Entrepreneurial Personality Trait Model under Entrepreneurial Intention for the Future in Surabaya / JEE, Vol. 9, No. 1, March 2020, pp 29-42

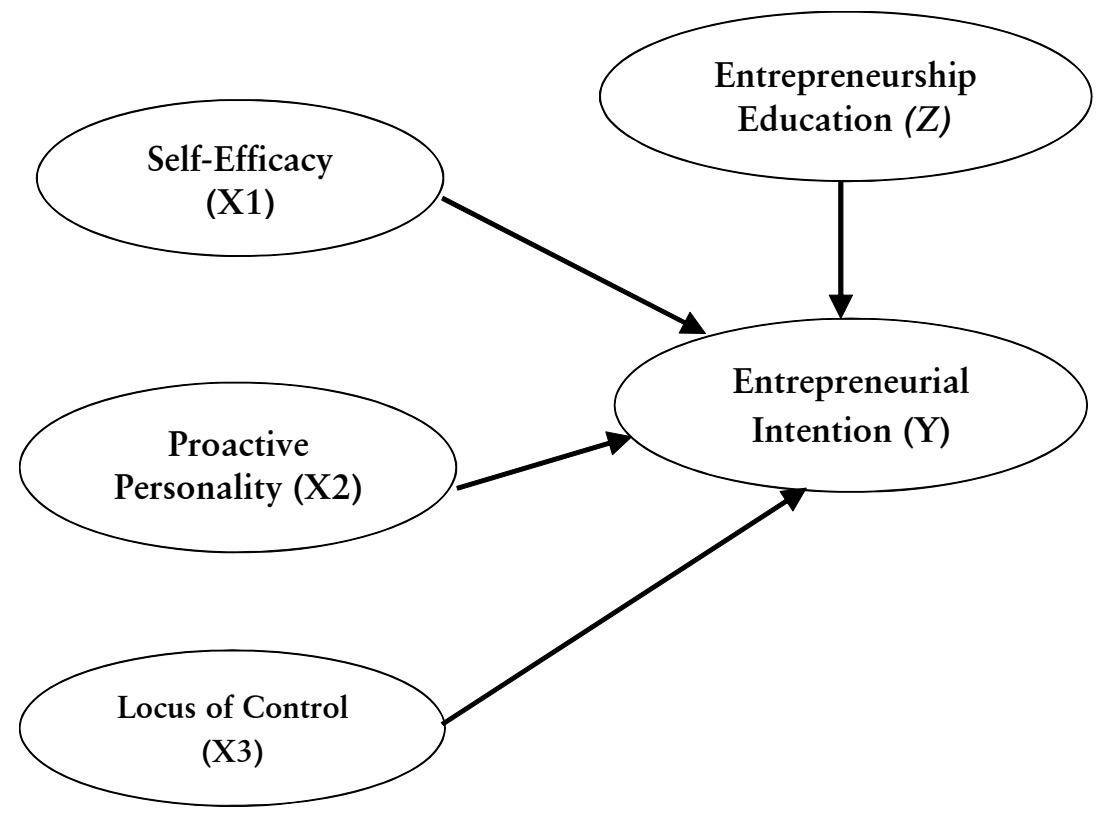

Picture 1 Research Model

Each of these variables has conceptual definitions and indicators that look like the following:

Table 1 Definitions and Variables Indicators

\begin{tabular}{|c|c|c|}
\hline Variable & Conceptual Definitions & Indicators \\
\hline Self-efficacy (X1) & $\begin{array}{l}\text { According to social cognitive } \\
\text { theory, self-efficacy is an } \\
\text { individual's ability to perform } \\
\text { certain tasks without regard to } \\
\text { what an individual has. He has } \\
\text { confidence in his efforts and is able } \\
\text { to maximize resources (Fuller et al., } \\
\text { 2018: 121). }\end{array}$ & $\begin{array}{l}\text { 1. Confidence in purpose. } \\
\text { 2. Confidence in solving difficult tasks. } \\
\text { 3. Believe in getting results that are } \\
\text { important to him or her. } \\
\text { 4. Confidence overcomes obstacles. } \\
\text { 5. Confidence in doing tasks effectively. } \\
\text { 6. Confidence always works best in } \\
\text { difficult situations. }\end{array}$ \\
\hline $\begin{array}{l}\text { Proactive Personality } \\
\text { (X2) }\end{array}$ & $\begin{array}{l}\text { Proactive personality is a } \\
\text { personality or trait that individuals } \\
\text { have that enables them to act } \\
\text { without being constrained by } \\
\text { external conditions and enables } \\
\text { them to influence their } \\
\text { environment to bring about change } \\
\text { (Li et al., 2018: 121). }\end{array}$ & $\begin{array}{l}\text { 1. Make long-term planning. } \\
\text { 2. Initiate immediate tasks. } \\
\text { 3. Act in anticipation of future problems. } \\
\text { Koe }(2016)\end{array}$ \\
\hline Locus of Control (X3) & $\begin{array}{l}\text { The situation in which individuals } \\
\text { trust everything they face in life is } \\
\text { still in their control and they will } \\
\text { always influence their decision } \\
\text { making (Adnyana \& Purnami, } \\
\text { 2016: 1165). }\end{array}$ & $\begin{array}{l}\text { 1. Be sure the results achieved are the } \\
\text { result of your own efforts. } \\
\text { 2. Self-leadership depends on one's own } \\
\text { ability. } \\
\text { 3. Success is the result of one's own efforts. } \\
\text { 4. Everything achieved is not the result of } \\
\text { luck }\end{array}$ \\
\hline
\end{tabular}


Vanessa \& Krismi Budi Sienatra / Effects of Entrepreneurship Education as an Entrepreneurial Personality Trait Model under Entrepreneurial Intention for the Future in Surabaya / JEE, Vol. 9, No. 1, March 2020, pp 29-42

\begin{tabular}{|c|c|c|}
\hline $\begin{array}{l}\text { Entrepreneur-ship } \\
\text { Education }(\mathrm{Z})\end{array}$ & $\begin{array}{l}\text { Entrepreneurial education, which is } \\
\text { a compulsory series of courses that } \\
\text { educates students to have the } \\
\text { experience of being an } \\
\text { entrepreneurial entrepreneur from } \\
\text { ideation to the emergence of a new } \\
\text { venture (Antonio, 2012: } 23 \text { ). }\end{array}$ & $\begin{array}{l}\text { 1. Learn about personal selling } \\
\text { 2. Learn about start-ups and online selling } \\
\text { 3. Learn about the retail business } \\
\text { 4. Learn about innovation in business } \\
\text { 5. Learn about international business } \\
\text { 6. Cultivate an entrepreneurial desire that } \\
\text { you can feel } \\
\text { 7. Increase the knowledge and insights of } \\
\text { entrepreneurship } \\
\text { 8. Increase awareness of existing business } \\
\text { opportunities. }\end{array}$ \\
\hline & & $\begin{array}{r}\text { Adnyana and Purnami (2016), } \\
\text { Antonio (2012) }\end{array}$ \\
\hline $\begin{array}{l}\text { Entrepreneurial } \\
\text { Intention }(\mathrm{Y})\end{array}$ & $\begin{array}{l}\text { Entrepreneurial intention is the } \\
\text { intention or desire of the individual } \\
\text { to become an entrepreneur as his } \\
\text { career choice and is an aspect that } \\
\text { will initiate entrepreneurship } \\
\text { (Karabulut, 2016: 16). }\end{array}$ & $\begin{array}{l}\text { 1. Self-preparedness to be an entrepreneur. } \\
\text { 2. The purpose of the profession is to } \\
\text { become an entrepreneur. } \\
\text { 3. Willingness to make every effort to start } \\
\text { and run your own company. } \\
\text { 4. Commit yourself to establishing future } \\
\text { endeavors. } \\
\text { 5. Have serious thoughts on becoming an } \\
\text { entrepreneur. } \\
\text { 6. Have a strong intention to set up a } \\
\text { business in the future. } \\
\text { Gelaidan and Abdullateef (2016) }\end{array}$ \\
\hline
\end{tabular}

Description:

$\mathrm{Y}=$ Entrepreneurial intention variable

$\alpha=$ Konstanta

$\beta_{1}=$ The regression coefficient variable of selfefficacy

$\beta_{2}=$ The regression coefficient variable of proactive personality

$\beta_{3}=$ The regression coefficient variable of $l-$ cus of control

$\mathrm{X}_{1}=$ self-efficacy variable

$\mathrm{X}_{2}=$ proactive personality variable

$\mathrm{X}_{3}=$ locus of control variable

$\mathrm{Z}=$ Entrepreneurship education variable

$\varepsilon=$ Error or residual

This study uses multiple linear regression analysis using the following three equations:

The first equation: $\mathrm{Y}=\alpha+\beta 1 \mathrm{X} 1+\beta 2 \mathrm{X} 2+$ $\beta 3 \mathrm{X} 3+\varepsilon$

The second equation: $\mathrm{Y}=\alpha+\beta 1 \mathrm{X} 1+\varepsilon$

The third equation: $\mathrm{Y}=\alpha+\beta 1 \mathrm{X} 1+\beta 2 \mathrm{Z}+$ $\beta 3 X 1 Z+\varepsilon$

The first equation is used to test the influence of the variables individually. The second and third equations are used to test the influence of entrepreneurship education variables as moderators between self-efficacy and entrepreneurial intention.

\section{RESULTS}

Multiple linear regression test data from variables of self-efficacy (X1), proactive personality (X2), and locus of control (X3) to entrepreneurial intention $(\mathrm{Y})$ were performed with the results shown in Table 2 below.

Table 2 Multiple Linear Regression Analysis of Variables of Self-efficacy, Proactive Personality, and Locus of Control on Entrepreneurial Intention

\begin{tabular}{lcccc}
\hline \multicolumn{1}{c}{ Variabel } & Beta & t hitung & Sig. & Keterangan \\
\hline (Constant) & 1.965 & 6.071 & 0.000 & \\
\hline Self-efficacy $(\mathrm{X} 1)$ & 0.197 & 2.606 & 0.010 & Signifikan \\
\hline Proactive Personality (X2) & 0.205 & 3.593 & 0.000 & Signifikan \\
\hline Locus of Control $(\mathrm{X} 3)$ & 0.239 & 3.891 & 0.000 & Signifikan \\
\hline $\mathrm{t}$ tabel $=1.97612, \mathrm{~d} f=148$ & & & & \\
$\alpha \quad=5 \%=0.05$ & & & & \\
\hline$\quad$
\end{tabular}

Source: Primary data (2019) 
Vanessa \& Krismi Budi Sienatra / Effects of Entrepreneurship Education as an Entrepreneurial Personality Trait Model under Entrepreneurial Intention for the Future in Surabaya / JEE, Vol. 9, No. 1, March 2020, pp 29-42

The question of whether the existence of a moderating variable will strengthen or strengthen the relationship of the independent variable to the dependent variable. This question can be found by comparing R2 values from the results of the regression equations that do not include the moderating variables to the $\mathrm{R} 2$ values of the results of the regression equations which include the moderating variables. Table 4 below shows data comparison analysis of the coefficient of determination of the self-efficacy variable (X1) on entrepreneurial intention (Y) by excluding moderation variables and by including entrepreneurship education $(Z)$ moderation variables:

Table 3 Comparison of Results of Analysis of Coefficient of Coefficients Included in Entrepreneurship Education Moderation Variables

\begin{tabular}{ccccc}
\hline Model & $\begin{array}{c}\mathrm{R} \text { (No } \\
\text { Moderation) }\end{array}$ & $\begin{array}{c}\mathbf{R}^{2} \text { (No } \\
\text { Moderation) }\end{array}$ & $\begin{array}{c}\mathbf{R} \text { (with } \\
\text { Moderation) }\end{array}$ & $\begin{array}{c}\mathbf{R}^{2} \text { (with } \\
\text { Moderation) }\end{array}$ \\
\hline 1 & 0.362 & 0.131 & 0.493 & 0.243 \\
\hline
\end{tabular}

Based on Table 3, it is known that the coefficient of determination (R2) of the linear regression coefficient of self-efficacy (X1) on entrepreneurial intention $(\mathrm{Y})$ that did not include the entrepreneurship education $(\mathrm{Z})$ moderation variable was 0.131 or $13.1 \%$. The figure means that the self-efficacy variable (X1) was able to explain the entrepreneurial intention $(\mathrm{Y})$ of University students by $13.1 \%$, while the remaining $86.9 \%$ was explained by other variables beyond the self-efficacy variable. The coefficient of determination (R2) of the regression equation results with the variable of self-efficacy (X1) on entrepreneurial intention (Y) with the inclusion variable of entrepreneurship education $(\mathrm{Z})$ of 0.243 or $24.3 \%$. Therefore, it is concluded that the $\mathrm{R} 2$ value of the equation that includes the moderation variable is greater than the equation that does not include the moderation variable, thus the existence of the entrepreneurship education $(Z)$ moderation variable will strengthen the relationship of selfefficacy (X1) to entrepreneurial intention (Y).

However, based on the moderated regression analysis, the results shown in Table 4 below are also obtained:

Table 4 Moderated Regression Results of Entrepreneurship Education Moderation Variables on Selfefficacy and Entrepreneurial Intention

\begin{tabular}{lcccl}
\hline \multicolumn{1}{c}{ Variabel } & $\begin{array}{c}\text { Unstandardized } \\
\text { Coefficients Beta }\end{array}$ & t hitung & Sig. & Description \\
\hline Self-efficacy $(\mathrm{X} 1)$ & 1.202 & 1.983 & 0.049 & Significant \\
\hline Entrepreneurship Education $(\mathrm{Z})$ & 1.231 & 2.102 & 0.037 & Significant \\
\hline $\begin{array}{l}\text { Self-efficacy } \mathrm{x} \text { Entrepreneurship } \\
\text { Education }(\mathrm{X} 1 \mathrm{xZ})\end{array}$ & -0.228 & -1.500 & 0.136 & Not Significant \\
\hline $\mathrm{t}$ tabel $=1.97612, \mathrm{~d} f=148$ & & & & \\
$\alpha \quad=5 \%=0.05$ & & & & \\
\hline$\quad$
\end{tabular}

$\alpha \quad=5 \%=0.05$

Source: Primary data (2019)

Table 5 shows that the computed values of the variables of self-efficacy (X1) and entrepreneurship education $(Z)$ are larger than those of the table. We can conclude that variables of self-efficacy (X1) and entrepreneurship education (Z) significantly influence entrepreneurial intention $(\mathrm{Y})$ variables. This is also supported by the significance values of the two variables smaller than 0.05 . However, it can be seen that the computational value of the predictor variable (X1xZ) is smaller than the table and its significance is greater than 0.05 , thus concluding that the variable has no significant effect on the entrepreneurial intention (Y) variable. Ghozali (2016: 214) explains that entrepreneurship education $(\mathrm{Z})$ variables are moderator predictor variables. Table 4.15 explains the coefficient values of the variables entrepreneurship education ( $Z$ ) and shows the significant effect. But the coefficient of the predictor variable (X1xZ) showed no significant effect. That is, the entrepreneurship education $(Z)$ variable acts as a moderator predictor variable where it can stand alone as an independent variable. 
Vanessa \& Krismi Budi Sienatra / Effects of Entrepreneurship Education as an Entrepreneurial Personality Trait Model under Entrepreneurial Intention for the Future in Surabaya / JEE, Vol. 9, No. 1, March 2020, pp 29-42

\section{DISCUSSION}

The Effect of Self-efficacy on Entrepreneurial Intention in Students

According to Primary (2017: 480) selfefficacy explains that individuals believe in their own ability to take action. Characteristics of a person with self-efficacy are that they are confident of achieving their goals, are able to accomplish difficult tasks, believe in achieving self-esteem, believe in overcoming obstacles, are confident in accomplishing their tasks, and are always doing their best difficult situations (Li et al., 2018: 125).

When students face difficulties in their business practices or in the tasks they receive in carrying out their entrepreneurship project, they believe they are capable of solving the problem. The more students believe that they are able to overcome all the difficulties that come with implementing the entrepreneurship project, the more committed students will be to run and sustain the entrepreneurship project they have developed.

The difficulties students face when sharing assignments refer to conflict management that results in group breaks, new marketing scope determinations, and the financial impact of the ongoing entrepreneurship project. If students have a strong intention to pursue their entrepreneurship project, they will be confident of solving all of these difficulties. It's because they really want to continue their entrepreneurship project. In addition, students are always confident that they will do their best to carry out the tasks found in the entrepreneurship project despite the difficult situation. The more confident students will always be at their best despite the difficult conditions and circumstances, the more determined they will be in their desire to run and develop the entrepreneurship project in progress. Examples of this are when students find difficult tasks such as reaching a profit target within a certain time frame, handling customer complaints involving shipping errors, and negotiating purchase prices with suppliers. If students have a strong desire to continue running and growing their entrepreneurship project, then students are confident that they will overcome all the difficulties they face in carrying out their tasks to achieve the best and maximum possible outcomes for their business continuity. This is because students have a strong desire to maintain their entrepreneurship project.

The results of this study are supported by the findings of Adnyana and Purnami (2016) and Ghozali and Sahrah (2017) which examined the effect of self-efficacy on entrepreneurial intention of S1 students and together came to the conclusion that entrepreneurial intention was positively and significantly influenced by self-efficacy.

\section{The Effect of Proactive Personality on Entre- preneurial Intention in Students}

According to Li et al. (2018: 121) proactive personality is an individual's personality or traits that makes them unstable by external conditions and enables the individual to influence his or her environment to bring about change. Characteristics of a person with a proactive personality include making long-term planning, taking initiative to carry out tasks, and acting in anticipation of future problems (Koe, 2016: 19).

Students on the entrepreneurship project will be more likely to anticipate the problems they will face as they are used to being proactive in reading opportunities and preparing for future events. As students have an innate tendency to anticipate issues that will arise in the 
Vanessa \& Krismi Budi Sienatra / Effects of Entrepreneurship Education as an Entrepreneurial Personality Trait Model under Entrepreneurial Intention for the Future in Surabaya / JEE, Vol. 9, No. 1, March 2020, pp 29-42

entrepreneurship project in the future, students will become more committed and serious in pursuing and successfully developing their entrepreneurship project. Examples of this can be seen from students preparing their entrepreneurship project for possible future conflicts of interest by writing a written agreement to implement it. Written agreements are also made by students in anticipation of the issue of shared disputes. If students have a strong intention to pursue the entrepreneurship project, then the student will take initiative to anticipate the problems that will be faced in the entrepreneurship project for the success of their entrepreneurship project. This is because students have a serious desire and mindset to effectively run and maintain their entrepreneurship project.

The results in this study are supported by the results of Delle and Amadu (2016) and Mustafa et al. (2016) who analyzed whether proactive personality influences entrepreneurial intention of students in Malaysia. These studies have found that proactive personality positively and significantly affects entrepreneurial intention.

\section{Influence of Locus of Control on Entrepreneur- ial Intention in Students}

According to Adnyana and Purnami (2016: 1165), locus of control is a condition where individuals believe everything they encounter in life is still in their control and they will always be influential in their decision making. Characteristics of a person with a locus of control include the belief that the outcome is selfdirected, self-leadership, confident that success is the result of one's own effort, and does not believe in luck (Wiriani et al., 2013: 1170).

Students on the entrepreneurship project believe that their leadership or self-leadership skills are influenced by their students because in the entrepreneurship project, each student acts as the leaders of the entrepreneurship project that determines the direction of their business success. The more students believe that they influence the leadership skills that will determine the final outcome of the entrepreneurship project, the more committed students will be to run and grow their business the best. An example of this is students participating in on-campus leadership training which is an activity program to educate students on the importance of leadership in day-to-day and business activities and function to train student-led leadership. As a result of this activity, the students are incorporated into their entrepreneurship project as the founders of a business that also handles group members and employees. If students have strong intentions and aspirations to pursue an entrepreneurship project, then students will believe that their ability to lead or rely on themselves can direct their business toward sustainable sustainability. This is because students have a strong desire to continue and develop their entrepreneurship project best to become a sustainable business.

The results of this study are supported by the results of Karabulut (2016) and Yasir et al. (2017) who examined the influence of locus of control on entrepreneurial intention students both concluded that entrepreneurial intention was positively and significantly influenced by locus of control.

Effect of Entrepreneurship Education on Moderating Self-efficacy and Entrepreneurial Intention

Entrepreneurship education according to Antonio (2012: 23) is an entrepreneurial education consisting of a series of compulsory courses that educate students to have the experience of 
Vanessa \& Krismi Budi Sienatra / Effects of Entrepreneurship Education as an Entrepreneurial Personality Trait Model under Entrepreneurial Intention for the Future in Surabaya / JEE, Vol. 9, No. 1, March 2020, pp 29-42

being an educated entrepreneur from ideation to the emergence of a new venture. The characteristics of entrepreneurship education include personal selling education, start-up and online selling, retail business, innovation in business, international business, growing entrepreneurial aspirations, enhancing entrepreneurship knowledge and insights, and raising awareness of existing business opportunities (Adnyana \& Purnami, 2016: 1169; Antonio, 2012: 24).

Students who face difficulties in business practice or in the tasks accepted in the entrepreneurship project believe they are capable of solving these difficulties. The more students believe that they are able to overcome all the difficulties that come with implementing the entrepreneurship project, the more committed students will be to run and sustain the entrepreneurship project they have developed. Entrepreneurship education gained by students will strengthen their confidence in overcoming and solving all the challenges and difficulties encountered in the entrepreneurship project and in turn strengthen the desire of students to continue and maintain the business of entrepreneurship project in progress. This is because entrepreneurship education provides students with new insights and skills that will enable them to better deal with the difficulties encountered in running the entrepreneurship project. Knowledge or the knowledge that students gain from entrepreneurship education will assist students in discovering new opportunities and methods for solving problems encountered in the entrepreneurship project. An example of this is how students can deal with complaints from online customers who have been taught at E2 which is the emphasis on startup and online selling. Stage E2 encourages students to start a new entrepreneurship project and to promote and sell online. Students are taught how to respond to and respond to customer complaints if customers submit complaints online, so they are more confident that they will be able to handle the difficulties and other tasks they will face in the entrepreneurship project. In this regard, the desire of the students to continue to pursue and maintain the business of entrepreneurship project is also increasing..

In addition, students are always confident that they will do their best to carry out the tasks found in the entrepreneurship project despite the difficult situation. The more confident students will always be at their best despite the difficult conditions and circumstances, the more determined they will be in their desire to run and develop the entrepreneurship project in progress. Entrepreneurship education gained by students will strengthen their confidence to always do their best in difficult situations when running an entrepreneurship project. In the meantime, entrepreneurship education will strengthen the strength of the student's intent to further and expand the business of entrepreneurship project in progress. Students are more confident in trying to do their best even in difficult situations where students who have entrepreneurship education will become more aware of new business opportunities. This awareness enables students to become more aware of new ways and opportunities that are more effective in solving the difficulties faced in the entrepreneurship project so that their business can survive. An example of this is when students find difficult tasks such as achieving a profit target within a certain time frame in the entrepreneurship project. As it has been taught in entrepreneurship education, students will seek and capitalize on new business opportunities to make it easier to achieve these profit targets, such as targeting new markets, using social media technology, or taking advantage of emerg- 
Vanessa \& Krismi Budi Sienatra / Effects of Entrepreneurship Education as an Entrepreneurial Personality Trait Model under Entrepreneurial Intention for the Future in Surabaya / JEE, Vol. 9, No. 1, March 2020, pp 29-42

ing market trends. Students are better prepared and able to do all the work and deal with the difficulties of the entrepreneurship project because of the entrepreneurship education they get. In this regard, students will become more determined in their desire to run and develop their entrepreneurship project.

The results of the analysis of the data from the moderated regression have also shown the results that the entrepreneurship education variable acts as a moderator predictor variable where the variables can stand alone as independent variables (Ghozali, 2016: 214). This means that entrepreneurship education conducted by the University does not only raise the students' self-esteem or self-efficacy because it is designed to educate students to gain knowledge and competence on how to set up a business and achieve success in a competitive economy. Competence for entrepreneurship will encourage students to become more entrepreneurial because they feel competent in the field. It also proves that student intentions for entrepreneurship can be created, not born.

The results of this study are supported by the results of Shahab et al. (2019) who examined the role of entrepreneurial education in strengthening the relationship of self-efficacy to entrepreneurial intention. The study concludes that entrepreneurial education strengthens the relationship of self-efficacy to entrepreneurial intention.

\section{CONCLUSION}

The study has analyzed the influence of entrepreneurship education as a moderator of the influence of entrepreneurial personality traits consisting of self-efficacy, proactive personality, and locus of control on entrepreneurial intention, the conclusion that can be drawn is that students are more confident in their ability to be entrepreneurial the self will also be higher. Furthermore, the higher the motivation for students to initiate change, the higher their intention to become self-sufficient entrepreneurs. Then, the higher the students' confidence in their ability to influence and change their business continuity and success, the more likely they are to become independent entrepreneurs. Entrepreneurship education builds student confidence. This knowledge enhances their ability to start new businesses.

The writer recommends educational institutions in particular University of Surabaya need to design curricula that strengthen students' desire to entrepreneurship not only in education, but also in terms of entrepreneurial personality traits students. This aspect includes self-efficacy, proactive personality, and locus of control, so students are expected to have stronger entrepreneurial intentions. In addition, the University is expected to adapt its entrepreneurship education curriculum so that early Entrepreneurship courses focus on student character development and empathy. Next, Entrepreneurship emphasized on the idea of learning personal selling skills for a student business entrepreneurship project. Further research is expected to delve further into entrepreneurial personality traits that influence entrepreneurial intention by examining other variables included in entrepreneurial personality traits besides selfefficacy, proactive personality, and locus of control to compare the magnitude of the influence of all variables entrepreneurial personality traits in their influence on entrepreneurial intention. In addition, it is hoped that future research may consider the use of entrepreneurship education variables as moderating variables in the relationship between elements of variable entrepre- 
Vanessa \& Krismi Budi Sienatra / Effects of Entrepreneurship Education as an Entrepreneurial Personality Trait Model under Entrepreneurial Intention for the Future in Surabaya / JEE, Vol. 9, No. 1, March 2020, pp 29-42

neurial personality traits as well as self-efficacy in its influence on entrepreneurial intention.

\section{REFERENCES}

Adnyana, I. G. \& Purnami, N. M. (2016). Pengaruh Pendidikan Kewirausahaan, Selfefficacy, dan Locus of Control pada Niat Berwirausaha. E-Jurnal Manajemen Unud, 5(2), 1160-1188.

Anggit, I. (2018, November 5). 10 Provinsi dengan Angka Pengangguran Paling Banyak. Retrieved on April 2, 2019 from https://www.cnbcindonesia.com/news/ 20181105145915-4-40638/10-provinsi-dengan-angka-pengangguran-paling-banyak.

Antonio, T. (2012). Inspiring Wednesday, Ciputra University Best Practice in Shaping Entrepreneurs in Higher Education. Jurnal Entrepreneur dan Entrepreneurship, 1(1), 2127.

Asikin, M. N. (2019, June 28). Hipmi Siap Dongkrak Jumlah Pengusaha Baru di Indonesia. Retrieved on October 11, 2019 from https:/www.jawapos.com/ekonomi/ bisnis/28/06/2019/hipmi-siap-dongkrakjumlah-pengusaha-baru-di-indonesia/

Baron, R. M. \& Kenny, D. A. (1986). The Moderator-Mediator Variable Distinction in Social Psychological Research: Conceptual, Strategic, and Statistical Considerations, Jurnal of Personality and Social Psychology, 51(6), 1173-1182.

Bungin, H. M. (2014). Metodologi Penelitian Kuantitatif: Komunikasi, Ekonomi, dan Kebijakan Publik Serta Ilmu-Ilmu Sosial Lainnya, Edisi 2. Jakarta: Prenada Media. Casero, J. C. D., Portillo, A. F., Escobedo, M. C. S., \& Mogollon, R. H. (2017). The Influence of University Context on Entre- preneurial Intentions, Entrepreneurial Universities, Innovation, Technology, and Knowledge Management, 1(1), 65-81.

Chipeta, E. M. \& Surujlal, J. (2017). Influence of Attitude, Risk Taking Propensity, and Proactive Personality on Social Entrepreneurship Intentions. Polish Journal of Management Studies, 15(2), 27-36.

CNN Indonesia. (2019, January 29). Lapangan Kerja Jadi Isu Krusial Hadapi Puncak Bonus Demografi. Retrieved on October 2, 2019 from https://www.cnnindonesia. com/ekonomi/20190129190415-532364850/lapangan-kerja-jadi-isu-krusialhadapi-puncak-bonus-demografi.

Delle, E. \& Amadu, I. M. (2016). Proactive Personality and Entrepreneurial Intention: Employment Status and Student Level as Moderators. Journal of Advance Management and Accounting Research, 3(7), 6981.

Dewi, S., Listyowati, D., \& Napitupulu, B. E. (2018), Bonus Demografi di Indonesia: Suatu Anugerah atau Petaka. Journal of Information System, Applied, Management, Accounting, and Research, 2(3), 17-23.

Dusak, I. K. \& Sudiksa, I. B. (2016), Pengaruh Pendidikan Kewirausahaan, Parental, dan Locus of Control terhadap Niat Berwirausaha Mahasiswa. E-Jurnal Manajemen Unud, 5(8), 5184-5214.

Fradani, A. C. (2014). Pengaruh Kecerdasan Adversitas, Pendidikan Kewirausahaan dalam Keluarga, Dukungan Keluarga, dan Efikasi Diri pada Intensi Berwirausaha Siswa SMK Negeri 2 Nganjuk. Jurnal Ekonomi Pendidikan dan Kewirausahaan, 2(2), 157-170.

Fuller, B., Liu, Y., Bajaba, S., Marler, L. E., \& Pratt, J. (2018). Examining how the Per- 
Vanessa \& Krismi Budi Sienatra / Effects of Entrepreneurship Education as an Entrepreneurial Personality Trait Model under Entrepreneurial Intention for the Future in Surabaya / JEE, Vol. 9, No. 1, March 2020, pp 29-42

sonality, Self-Efficacy, and Anticipatory Cognitions of Potential Entrepreneurs Shape Their Entrepreneurial Intentions. Personality and Individual Differences, 125, 120-125.

Gelaidan, H. M. \& Abdullateef, A. O. (2017). Entrepreneurial Intentions of Business Students in Malaysia: The Role of SelfConfidence, Educational and Relation Support. Journal of Small Business and Enterprise Development, 24(1), 54-67.

Ghozali, I. (2016). Aplikasi Analisis Multivariete dengan Program IBM SPSS 23 Edisi 8. Semarang: Badan Penerbit Universitas Diponegoro.

Ghozali, I. dan Sahrah, A. (2017). Pengaruh Efikasi Diri dan Kecerdasan Menghadapi Rintangan terhadap Niat Berwirausaha pada Mahasiswa Fakultas Ekonomi di Universitas Bangka Belitung. Jurnal Society, 5(1), 33-43.

Gujarati, D. N., Porter, D. C., \& Gunasekar, S. (2017). Basic Econometrics, 5th Edition.

New York: Mcgraw-Hill/Irwin.

Handaru, A. W., Parimita, W., \& Mufdhalifah, I. W. (2015). Membangun Intensi Berwirausaha melalui Adversity Quotient, Selfefficacy, dan Need for Achievement. JMK, 17(2), 155-166.

Hermanto, B. \& Suryanto, S. (2017). Entrepreneurship Ecosystem Policy in Indonesia, Mediterranean Journal of Social Sciences, 8(1), 110-115.

Jailani, M., Rusdarti, R., \& Sudarma, K. (2017). Pengaruh Kewirausahaan, Motivasi Belajar, Sosial Ekonomi Orang Tua dan Self-efficacy Terhadap Minat Berwirausaha Siswa. Journal of Economic Education, 6(1), 52-59.

Janie, D.N. (2012). Statistik Deskriptif \& Regresi Linier Berganda dengan SPSS. Semarang: Semarang University Press.
Jubari, I. A., Hassan, A., \& Liñán, F. (2018). Entrepreneurial Intention among University Students in Malaysia: Integrating SelfDetermination Theory and The Theory of Planned Behavior. International Entrepreneurship and Management Journal, 1, 120.

Karabulut, A.T. (2016). Personality Traits on Entrepreneurial Intention, Procedia - Social and Behavioral Sciences, 229, 2-21.

Karimi, S., Biemans, H. J. A., Lans, T., Mohammad, C., \& Mulder, M. (2016). The Impact of Entrepreneurship Education: A Study of Iranian Students' Entrepreneurial Intentions and Opportunity Identification. Journal of Small Business Management, 54(1), 187-209.

Khalifa, A. H. \& Dhiaf, M. M. (2016). The Impact of Entrepreneurship Education on Entrepreneurial Intention: The UAE Context. Polish Journal of Management Studies, 14(1), 119-128.

Koe, W. L. (2016). The Relationship between Individual Entrepreneurial Orientation (IEO) and Entrepreneurial Intention. Koe Journal of Global Entrepreneurship Research, 6(13), 13-24.

Kolvereid, L. \& Moen, Ø. (1997). Entrepreneurship among business graduates: does a major in entrepreneurship make a difference? Journal of European Industrial Training, 21(4), 154-160.

Kruse, P., Wach, D., Costa, S., \& Moriano, J. A. (2018). Values Matter, Don't They? Combining Theory of Planned Behavior and Personal Values as Predictors of Social Entrepreneurial Intention. Journal of Social Entrepreneurship, 145(1), 1-29.

Kuwado, F. J. (2018, April 5). Jumlah Entrepreneur di Indonesia Jauh di Bawah Negara Maju, Ini Kata Jokowi. Retrieved on Oc- 
Vanessa \& Krismi Budi Sienatra / Effects of Entrepreneurship Education as an Entrepreneurial Personality Trait Model under Entrepreneurial Intention for the Future in Surabaya / JEE, Vol. 9, No. 1, March 2020, pp 29-42

tober 11, 2019 from https://nasional. kompas.com/read/2018/04/05/17261391/ jumlah-entrepreneur-di-indonesia-jauh-dibawah-negara-maju-ini-kata-jokowi.

Li, C., Naz, S., Dodor, A., Ashraf, S. F., \& Akolgo, I. G. (2018). An Investigation of the Relationship between Proactive Personality and Entrepreneurial Intentions Using PLS-SEM among Potential Entrepreneurs in Pakistan. WALIA Journal, 34(1), 120-131.

Luca, M. R., Cazan, A. M., \& Tomulescu, D. (2013). Entrepreneurial Personality in Higher Education, Procedia - Social and Behavioral Sciences, 8, 1045-1049.

Maolani, R. A. \& Cahyana, U. (2015). Metodologi Penelitian Pendidikan. Jakarta: Rajawali Press.

Maresch, D., Harms, R., Kailer, N., \& Wurm, B. W. (2016), The Impact of Entrepreneurship Education on the Entrepreneurial Intention of Students in Science and Engineering Versus Business Studies University Programs. Technological Forecasting \& Social Change, 104, 172-179.

Mjs \& Tim. (2018, Oktober 19). Hanya 3,1 Persen Penduduk Produktif di RI yang Wirausaha. Retrieved on Maret 30, 2019 from https://www.cnnindonesia.com/ekonomi/20181018210657-92-339664/hanya31-persen-penduduk-produktif-di-ri-yangwirausaha.

Mustafa, M.J., Hernandez, E., Mahon, C., \& Chee, L. K. (2016). Entrepreneurial Intentions of University Students in an Emerging Economy: The Influence of University Support and Proactive Personality on Students' Entrepreneurial Intention. Journal of Entrepreneurship in Emerging Economies, 8(2), 162-179.
Prabhu, V. P., McGuire, S. J., Drost, E. A., \& Kwong, K. K. (2012). Proactive Personality and Entrepreneurial Intent: Is Entrepreneurial Self-Efficacy A Mediator or Moderator? International Journal of Entrepreneurial Behaviour \& Research, 18(5), 559-586.

Priyatno, D. (2014). SPSS 22: Pengolah Data Terpraktis. Yogyakarta: Penerbit ANDI.

Priyono. (2016). Metode Penelitian Kuantitatif. Sidoarjo: Zifatama Publishing.

Putra, B. P. (2018). Peningkatan Jumlah Wirausahawan di Indonesia Melalui Kolaborasi Akademisi - Pelaku Usaha - Mahasiswa. Economicus, 9(1), 63-71.

Ranto, D. W. P. (2016). Membangun Perilaku Entrepreneur pada Mahasiswa Melalui Entrepreneurship Education. JBMA, 3(1), 79-86.

Robinson, P. B. \& Sexton, E. A. (1994). The Effect of Education and Experience on Self-Employment Success. Journal of Business Venturing, 9 (2), 141-156.

Setiawan, J. L. (2014). Examining Entrepreneurial Self-Efficacy among Students. Procedia - Social and Behavioral Sciences, 115, 235242.

Shahab, Y., Chengang, Y., Arbizu, A. D., \& Haider, M. J. (2019). Entrepreneurial SelfEfficacy and Intention: Do Entrepreneurial Creativity and Education Matter? International Journal of Entrepreneurial Behavior \& Research, 25(2), 259--280.

Shepherd, D. A. \& Douglas, E. J. (1997). Is Management Education Developing, or Killing, the Entrepreneurial Spirit? United States Association for Small Business and Entrepreneurship, 1, 1-19.

Shinnar, R. S. Hsu, D. K., \& Powell, B. C. (2014). Self-Efficacy, Entrepreneurial In- 
Vanessa \& Krismi Budi Sienatra / Effects of Entrepreneurship Education as an Entrepreneurial Personality Trait Model under Entrepreneurial Intention for the Future in Surabaya / JEE, Vol. 9, No. 1, March 2020, pp 29-42

tentions, and Gender: Assessing the Impact of Entrepreneurship Education Longitudinally. The International Journal of Management Education, 12, 561-570.

Siyoto, S. \& Sodik, M. A. (2015). Dasar Metodologi Penelitian. Yogyakarta: Literasi Media Publishing.

Srimulyani, V. A. (2013). Analisis Pengaruh Kecerdasan Adversitas, Internal Locus of Control, Kematangan Karir terhadap Intensi Berwirausaha pada Mahasiswa Bekerja (Studi Empiris pada Mahasiswa Kelas Karyawan Unika Widya Mandala Madiun). Widya Warta,1, 96-110.

Suharti, L. \& Sirine, H. (2011). Faktor-Faktor yang Berpengaruh Terhadap Niat Kewirausahaan (Entrepreneurial Intention): Studi Terhadap Mahasiswa Universitas Kristen Satya Wacana, Salatiga. Jurnal Manajemen dan Kewirausahaan, 13(2), 124-134.

Sujarweni, V. W. (2014). SPSS untuk Penelitian. Yogyakarta: Pustaka Baru Press.

Sujarweni, V. W. (2015). Statistik untuk Bisnis dan Ekonomi. Yogyakarta: Pustaka Baru Press.

Tikoria, P. T. (2017). Predictors of Social Entrepreneurial Intention: An Empirical Study, South Asian Journal of Business Studies, 6(1), 1-41.

Tornikoski, E. T. \& Maalaoui, A. (2019). Critical Reflections - The Theory of Planned Behaviour: An Interview with Icek Ajzen with Implications for Entrepreneurship Research. International Small Business Journal, 37(5), 536-550.
Trivedi, R. (2016). Does University Play Significant Role in Shaping Entrepreneurial Intention? A Cross-Country Comparative Analysis. Journal of Small Business and Enterprise Development, 23(3), 790-811. Utami, C. W. (2017). Attitude, Subjective Norms, Perceived Behavior, Entrepreneurship Education and Self-efficacy toward Entrepreneurial Intention University Student in Indonesia. European Research Studies Journal, 20(2A), 475-495.

Verma, V. K. \& Chandra, B. (2017). An Application of Theory of Planned Behavior to Predict Young Indian Consumers' Green Hotel Visit Intention. Journal of Cleaner Production, 172, 1152-1162.

Wiriani, W., Piatrini, P. S., Ardana, K., \& Juliarsa, G. (2013). Efek Moderasi Locus of Control pada Hubungan Pelatihan dan Kinerja pada Bank Perkreditan Rakyat di Kabupaten Badung. Jurnal Ilmiah Akuntansi dan Bisnis, 8(2), 99-105.

Yang, J. H. (2018). The Effect of Entrepreneurship Education on Entrepreneurial Leadership of University Students. Asia-Pacific Journal of Business Venturing and Entrepreneurship, 13(3), 59-69.

Yasir, N., Liren, A., Mehmood, N., \& Arfat, Y. (2017). Impact of Personality Traits on Entrepreneurial Intention and Demographic Factors as Moderator. International Journal of Entrepreneurship, 22(4), 19394675. 